\title{
Health Care Documentation Management in Hospital Conditions
}

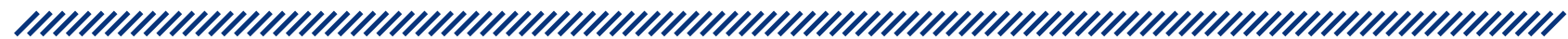

${ }^{1,2}$ Amer Ovčina

1 Selveta Mušanović

1 Ernela Eminović

2 Nada Spasojević

3 Amela Hajdarević

2 Jasmina Marušić

1 Clinical Center of the University of Sarajevo

2 University „Vitez” in Vitez, Faculty Health studies

3 Regional Medical Center „Dr. Safet Mujić” Mostar

\section{Summary}

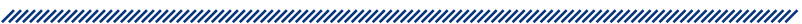

Healthcare documentation or nursing documentation as often used in practice is the name of an indispensable part of a patient's medical documentation, and documentation is an integral part of a nurse's daily work. Documenting health care in the hospital means recording data on all procedures performed, during the entire health care process for the individual, all for the purpose of systematic monitoring, planning and evaluation of the quality of health care. Nursing documentation serves as a means of communication between the team and is of great importance for the quality and continuity of health care.

AIMS: 1 - To determine the existence of health care documentation in hospital health care institutions; 2 - Examine the importance and purpose of documenting health care among nurses-medical technicians; 3 - Examine the practice of nurses-medical technicians in the process of administering health care; 4 - Present quality indicators that are monitored and analyzed through health care documentation; 5 - Compare the obtained results in two examined areas.

METHODS: This research was conducted in two geographically separate areas of Sarajevo and Travnik. The study involved 210 respondents, 147 nurses-technicians employed at the Clinical Center of the University of Sarajevo and 63 nurses-technicians employed at the General Hospital in
Travnik. Data collection for research was carried out by exploratory and descriptive method. An original authorized questionnaire was used for the descriptive research. The questionnaire was made available to respondents in the electronic form trough Google Forms. The anonymity of the respondents was fully guaranteed. The survey was conducted in the period from July 15-August 15, 2019.

RESULTS: At the Clinical Center of the University of Sarajevo (CCU), $98 \%$ of respondents use health care documentation forms on a daily basis, and at the General Hospital Travnik $77.8 \%$ of respondents. In CCU Sarajevo, respondents use more standardized forms of health care documentation, $97.6 \%$, compared to respondents in the General Hospital Travnik, where the documenting is carries out in nursing records, $74.6 \% .68 \%$ of respondents at CCU Sarajevo believe that documentation contributes to the evaluation of nursing services, while only $19 \%$ of respondents at General Hospital Travnik believe the same. As the most common shortcomings, the respondents state the lack of computer technology in the department in $74.3 \%$, then adequate premises for document administration in $37.6 \%$, the lack of forms in printed form in $32.1 \%$ and 6 or $2.3 \%$ respondents did not answer this question.

In both institutions, the biggest shortcoming is the problem of computer equipment in the department, in $70.7 \%$ in CCU Sarajevo and $82.5 \%$ in General Hospital Travnik.

CONCLUSIONS: The research found that over $95 \%$ of respondents use standardized health care processes in their daily practice, document health care, know the basic purpose and monitor health care indicators. More than $90 \%$ of respondents in both study groups use health care documentation to plan health care and monitor its outcomes. More than half of respondents in both study groups stated that documenting health care is a problem because it consumes a lot of time. A larger number of respondents from both groups, as many as $30 \%$, state that they do not use the data from the health care documentation for any purpose. The lack of workers in the health care process, insufficient knowledge of information technologies, and the lack of an information system represent an aggravating circumstance in documenting the health care process. 
Keywords: documentation, health care, nursing, practice, teamwork, autonomy, laws.

Article received: 10.07.2020.

Article accepted: 01.09.2020.

https://doi.org/10.24141/1/6/2/3

Corresponding author:

Amer Ovčina

A: Klinički centar Univerziteta u Sarajevu, Disciplina za nauku i nastavu, Organizaciona jedinica za kvalitet i sigurnost zdravtvenih usluga

Bolnička 25, 71000 Sarajevo

E-mail: amer.ovcina@kcus.ba

T: +38733298560

\section{Introduction}

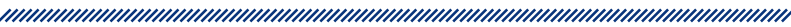

By documenting the health care process, a systematic approach to the patient's problems is achieved, which is of great importance in nursing practice. ${ }^{1}$

By administering the nurse's documentation, the nurse confirms that she/he has applied knowledge, skills and attitudes in its work, by applying critical thinking in accordance with the standards of nursing practice. ${ }^{2,3}$

Nowadays, when the level of education of nurses-medical technicians is significantly higher than a few decades ago, their responsibility is also greater. ${ }^{4}$

In the Law on Nursing and Midwifery of the Federation of Bosnia and Herzegovina, Article 35 states that a nurse-medical technician in the performance of his/her activity is obliged to keep nursing or midwifery documentation, which is part of medical documentation and which records procedures performed, in accordance with special regulations on health care records. ${ }^{5}$

By documenting the health care process ensures good communication between nurses, with other nurses, the medical team (doctors, laboratory technicians, etc.), non-medical staff, family and the health system throughout the patient care process. Therefore, data collection is an unavoidable step in the health care process. ${ }^{5}$

Health care documentation also serves as legal protection - a document that confirms the facts and claims in the event of a possible dispute or conflict. It is also a source of proof of the responsibility of each individual health care provider, but also proof in court proceedings. ${ }^{6}$

hrough documentation, it is possible to monitor costs in relation to efficiency, then it is a source of information on the basis of which research can obtain significant results useful for the development of nursing practice and is one of the standards of nursing at the international level. ${ }^{7}$

Kalauz and associates state that by documenting the health care process, nurses establish a new identity for their profession, ensuring its integrity and autonomy. ${ }^{8}$

Nurses are obliged to continuously improve their scope of work and innovate their activities in the health care process. In order to improve their work and ensure the satisfaction of their patients, it is necessary to adequately document all services from the moment the patient is admitted to the hospital. ${ }^{9}$

Monitoring of the course of health care is carried out during the patient's stay in the ward, and then their processing periodically and, if necessary, summarizes the nurse's diagnosis. It forms the basis for deciding on the goals and procedures to be applied to the patient. They evaluate their success through a health care discharge letter which is a mandatory part of the nursing documentation. ${ }^{10}$

In order to ensure the quality of health services, it is necessary to provide a systematic approach to adequate documentation, which means good education of nurses, provision of resources and implementation of the information system. ${ }^{11}$

\section{Goals}

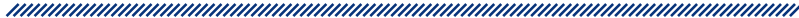

1. To determine the existence of health care documentation in hospital health care institutions;

2. Examine the importance and purpose of documenting health care among nurses-medical technicians;

3. Examine the practice of nurses-medical technicians in the process of administering health care;

4. Present quality indicators that are monitored and analyzed through health care documentation;

5. Compare the obtained results in two examined areas. 


\section{Methods}

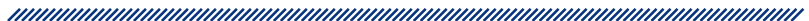

The research is descriptive. Methods used are: inductions, deductions and compilations.

This research was conducted in two geographically separate areas, Sarajevo and Travnik.

210 respondents participated in the study, 147 nursesmedical technicians employed at the Clinical Center of the University of Sarajevo (CCUS) and 63 nursesmedical technicians employed at the General Hospital Travnik. The selection of respondents was done by random selection. The research included nurses-medical technicians without selection according to education and function in the workplace, and they are employed in hospital wards. The research was conducted in the period from June 15 until August 15, 2019.

An original author's questionnaire was created for the research, created on the basis of previous experiences in practice and with the help of a review of professional and scientific literature. The questionnaire was created in the "Google forms" and was available to respondents via e-mail invitation.

The results are presented tabularly and graphically by number of cases and percentages, and arithmetic means with standard deviation and range of values.

Testing of differences between institutions was performed using the Ficher exact test, the chi-square test and the Student's t test at the significance level of 95\%.

The analysis was conducted using the IBM Statistics SPSS v23.0 software (Chicago Illinois, USA).

\section{Results}

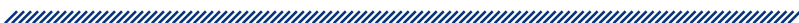

The total sample included 210 responses to the questionnaire on nursing documentation, which was answered by 63 nurses-medical technicians of the Travnik Hospital, which is $30.0 \%$, and 147 nurses-medical technicians from the Clinical Center of the University of Sarajevo, which makes $70.0 \%$ of the total sample.

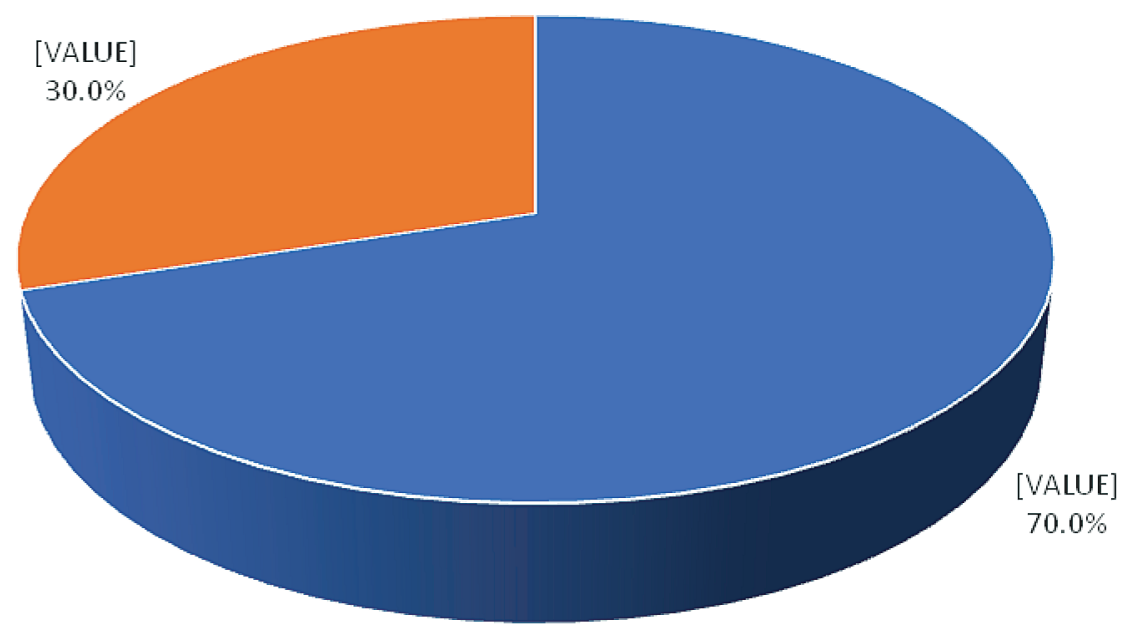

- Clinical Center of University of Sarajevo = General hospital Travnik 


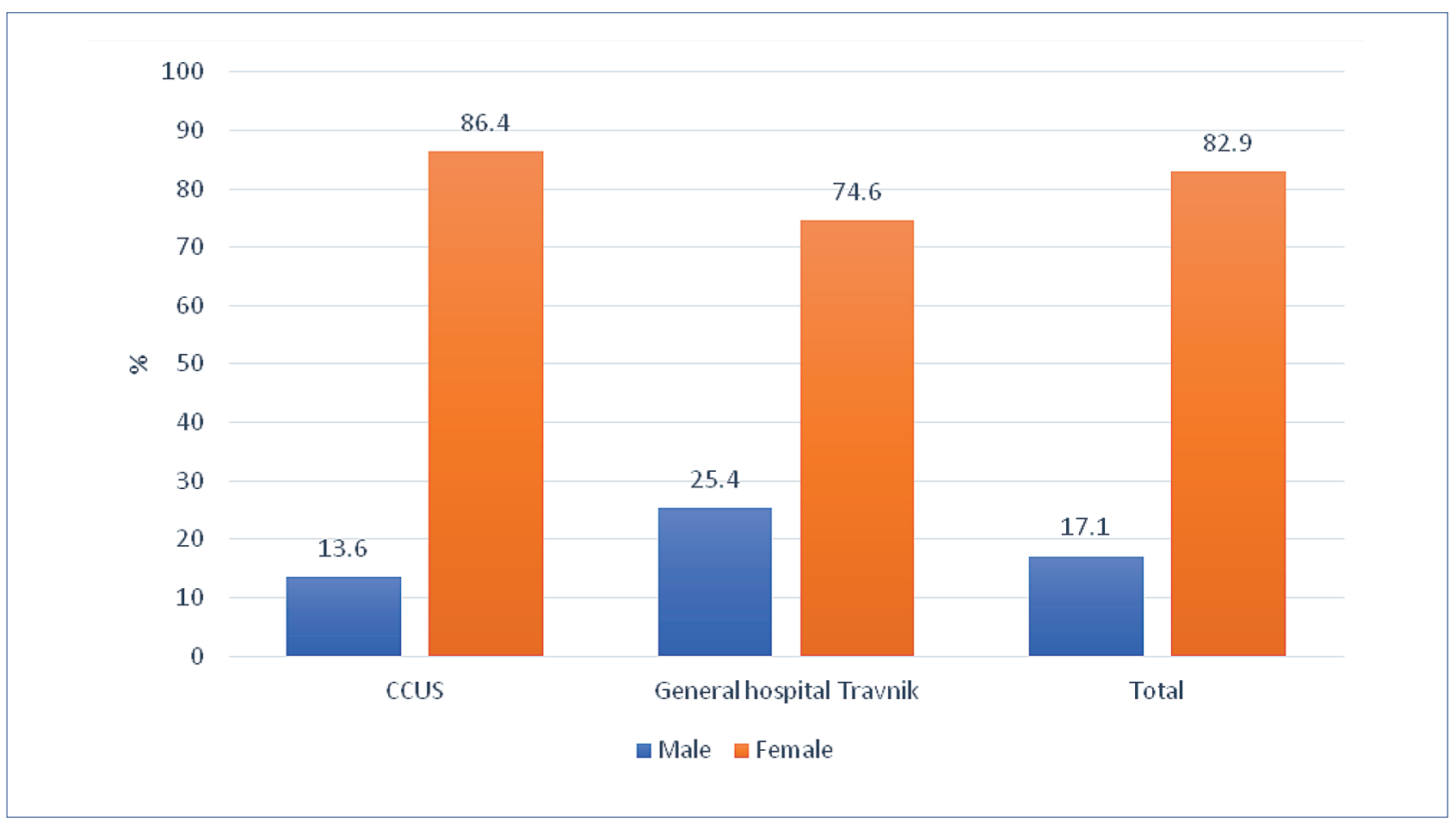

Figure 2. Gender structure of respondents

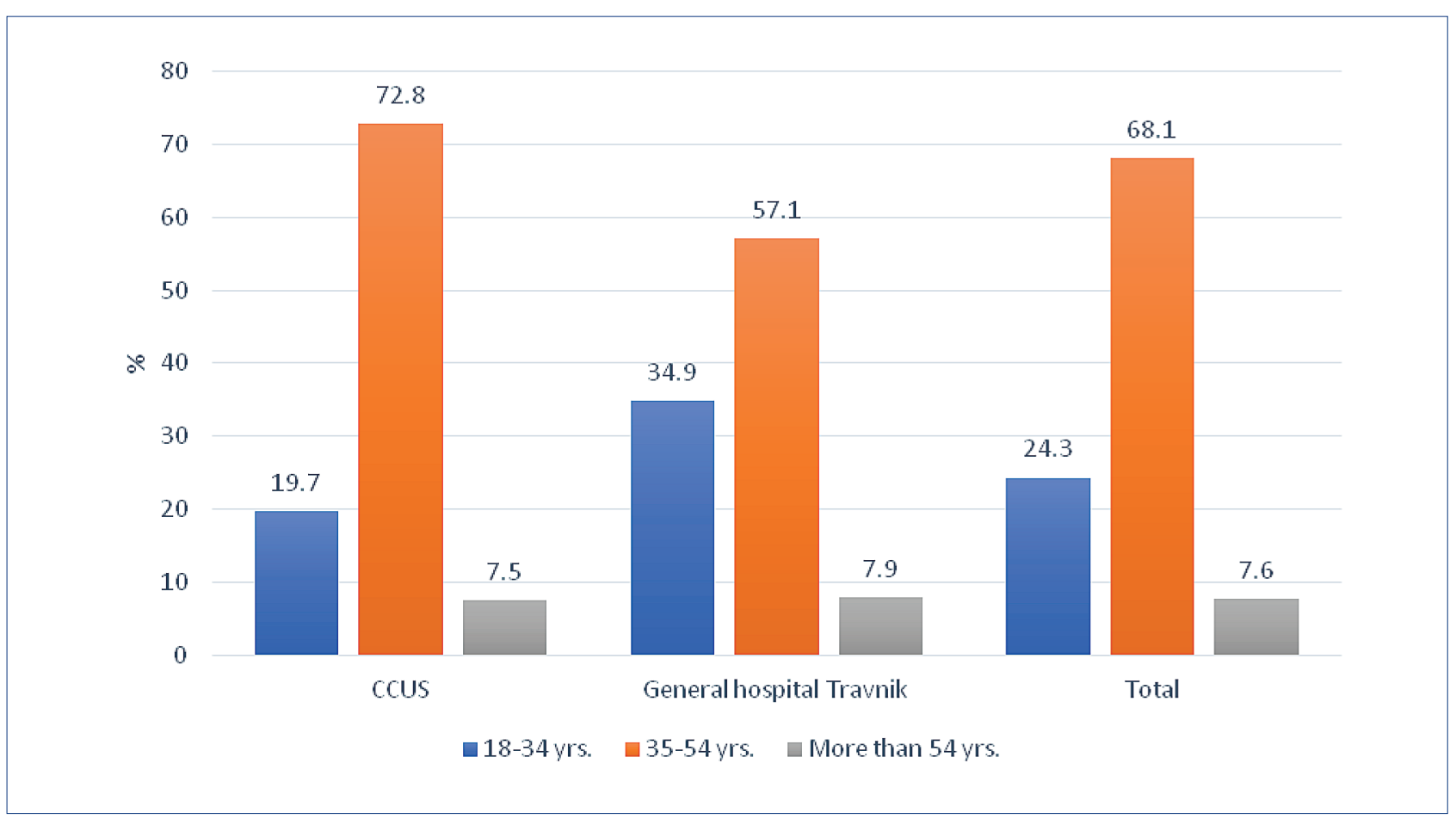

Figure 3. Age structure of respondents 


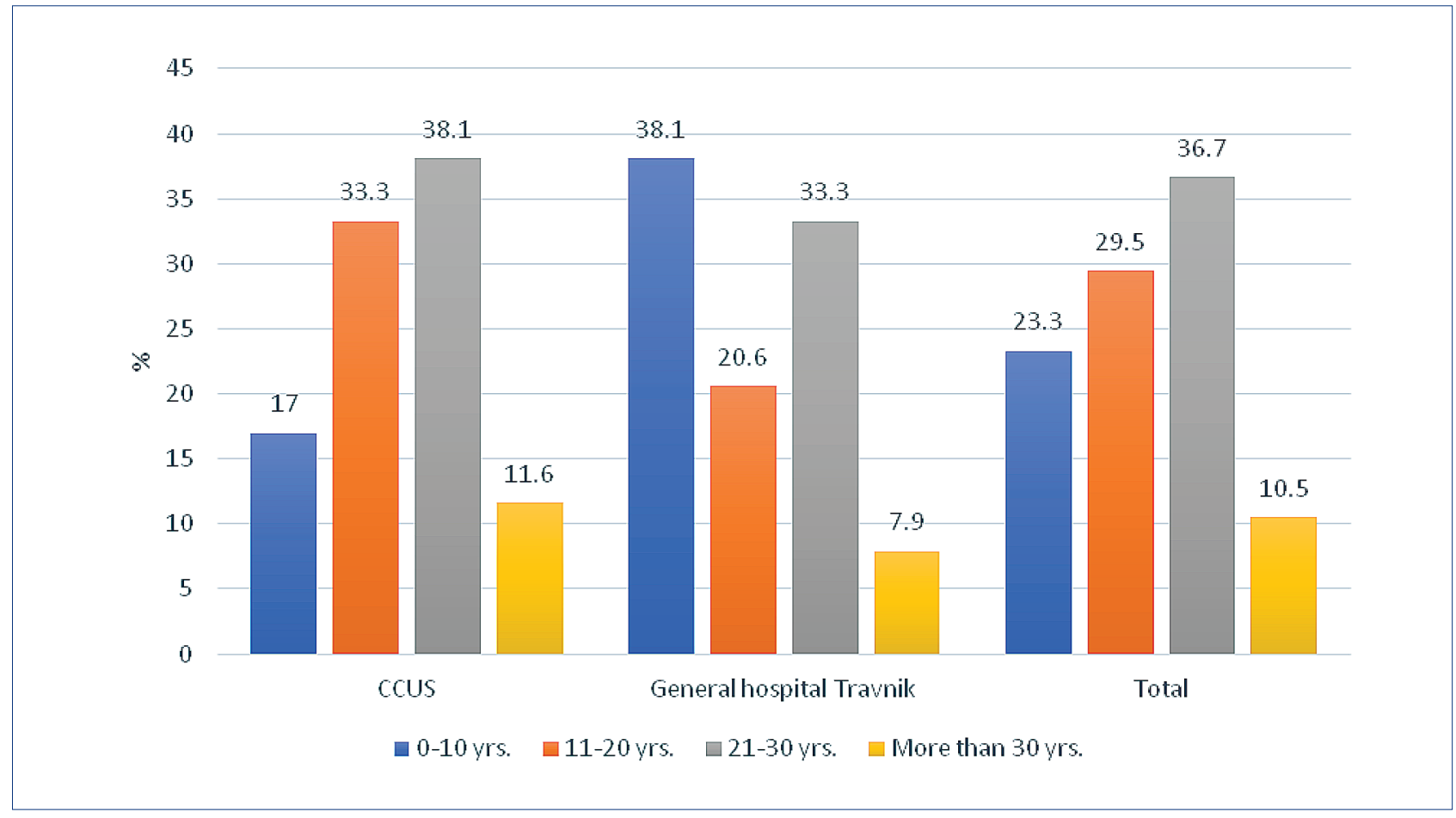

Figure 4. Years of work experience of the respondents

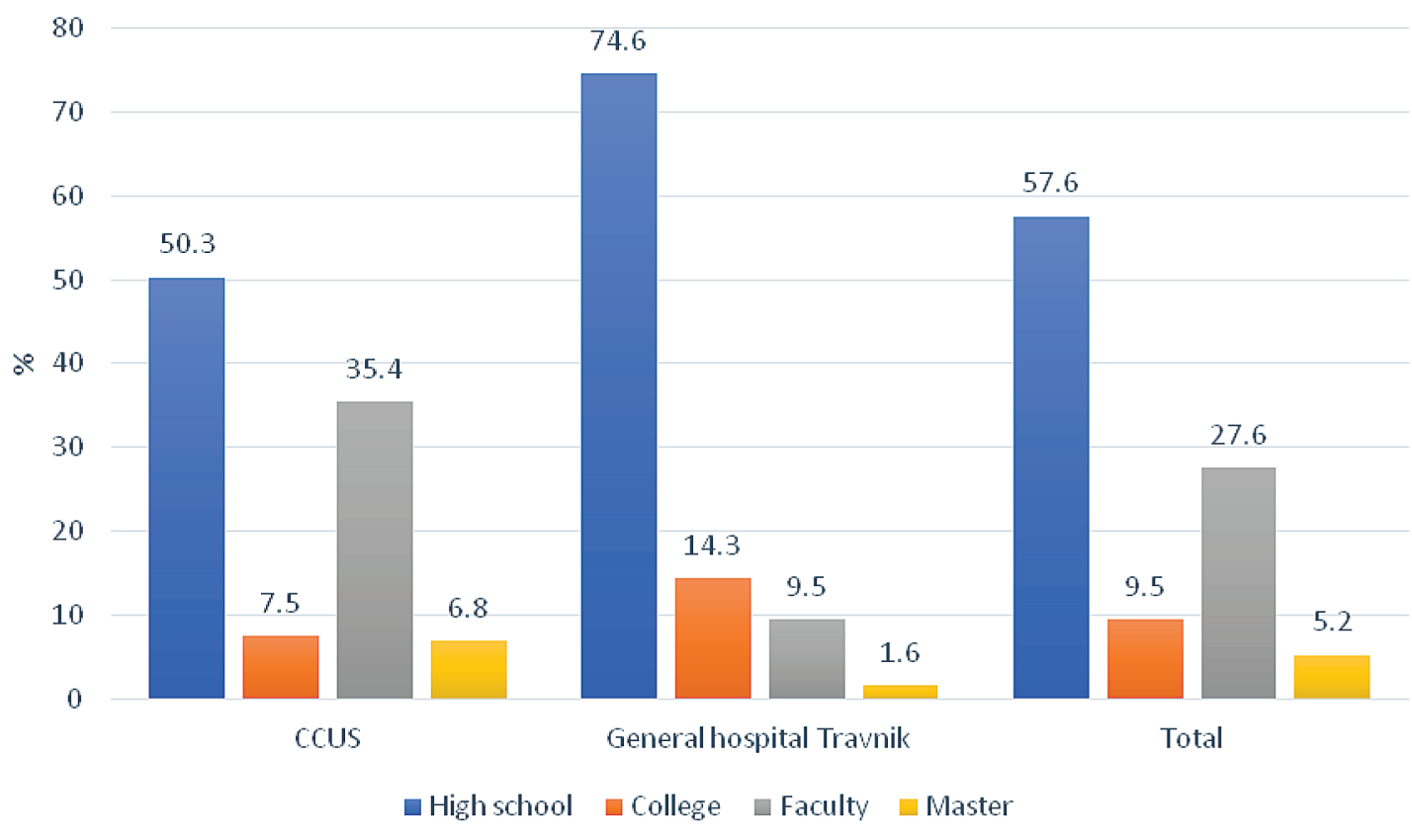




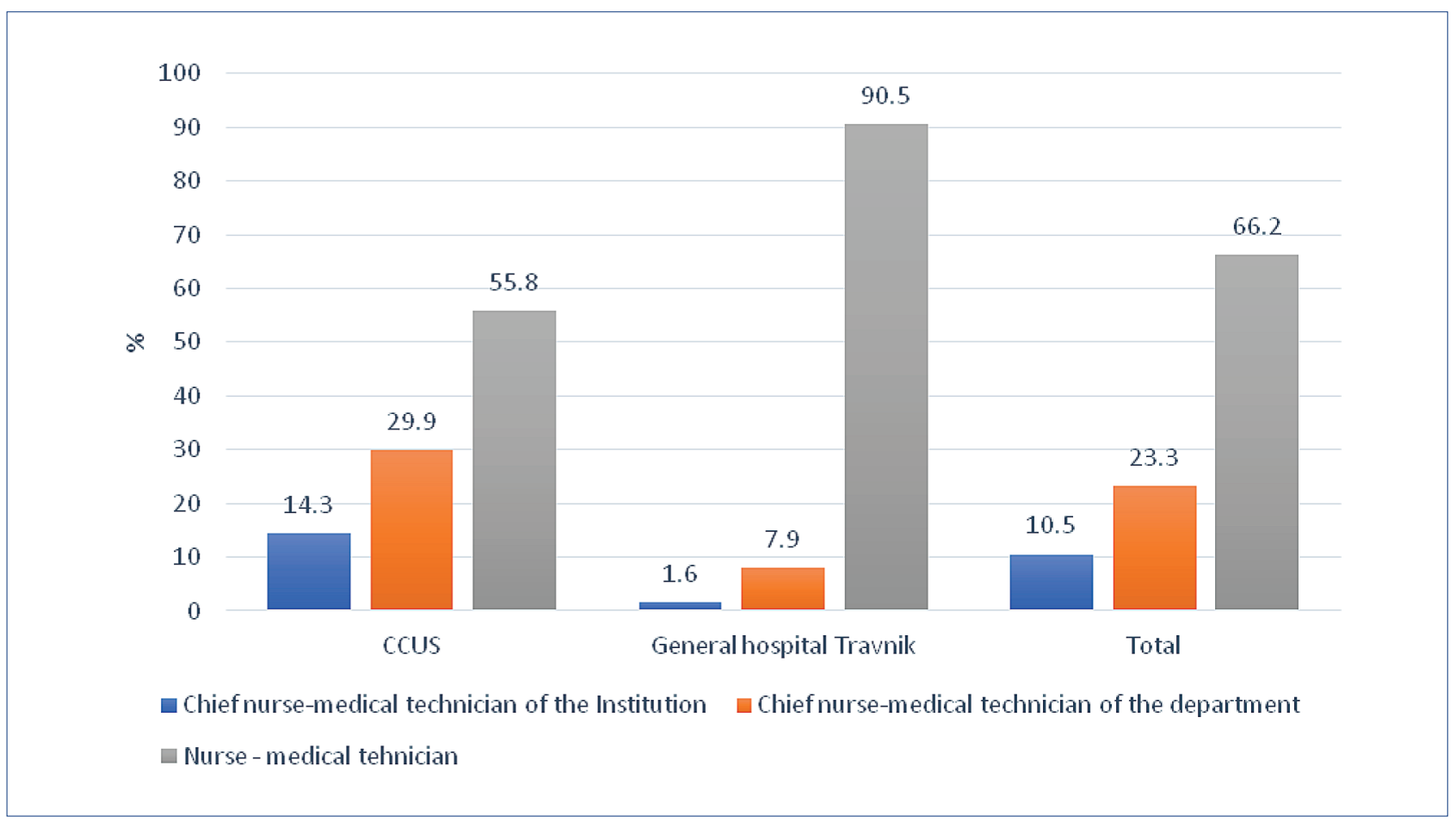

Figure 6. Representation of respondents by function in the workplace

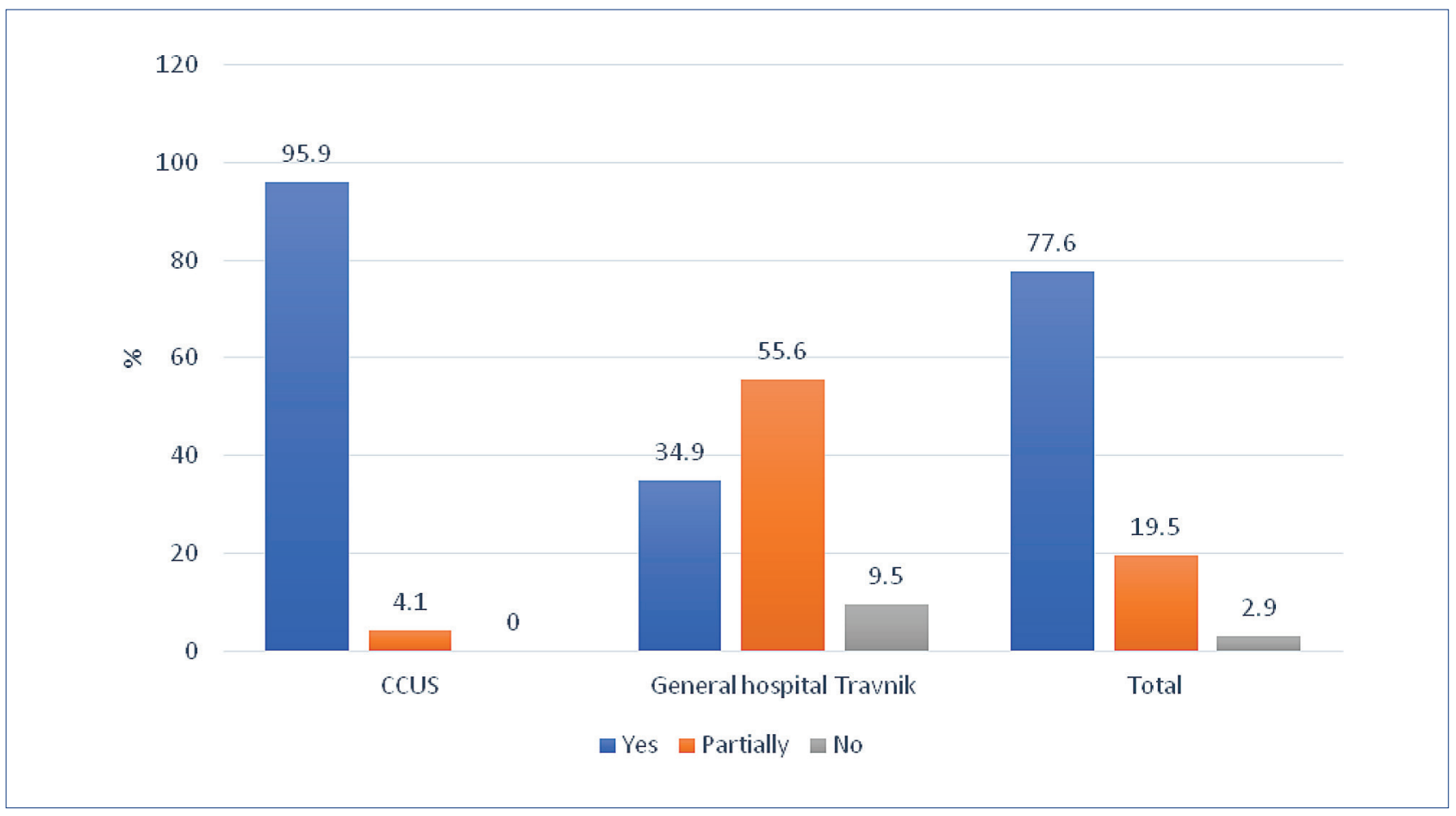




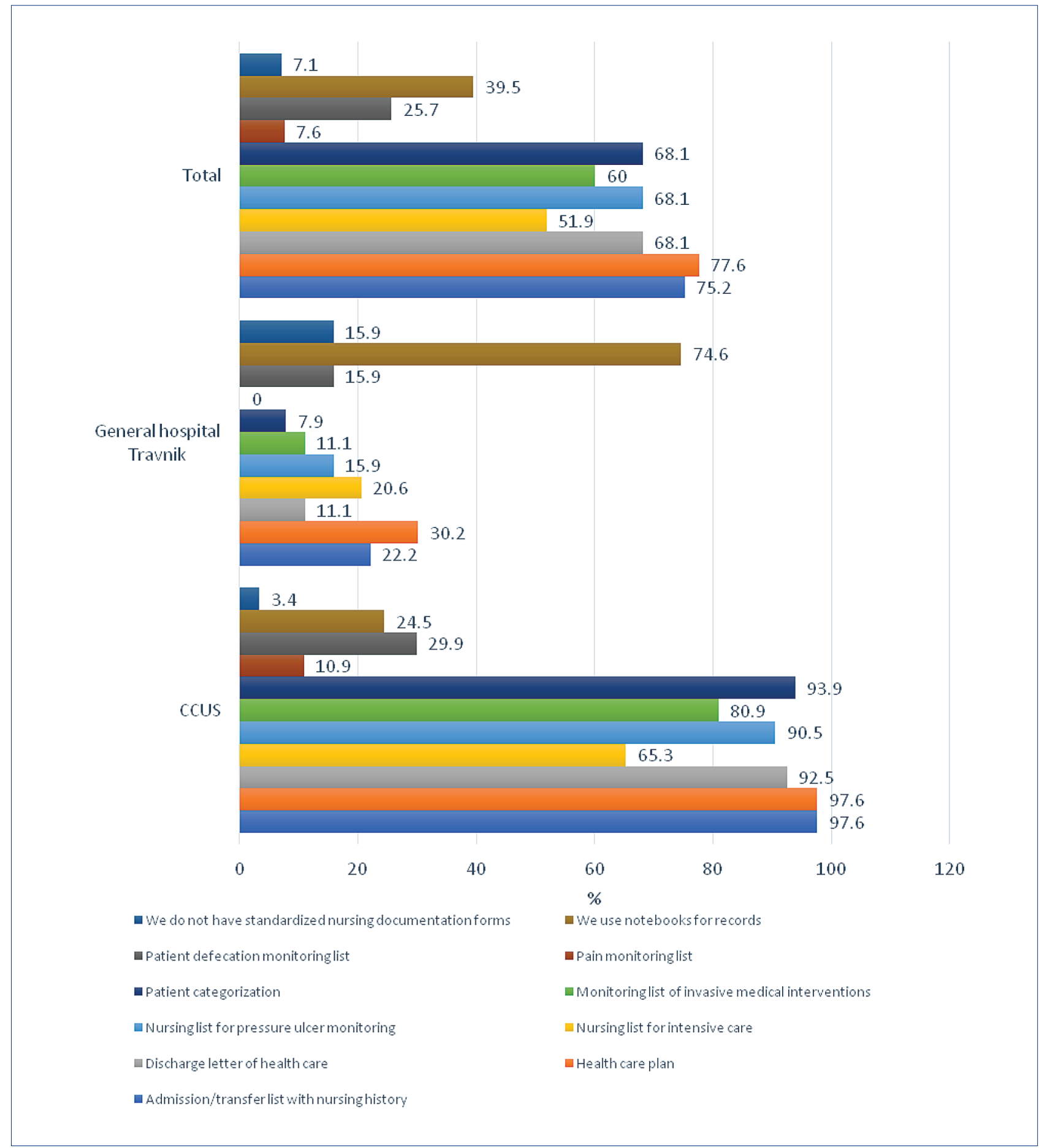

Figure 8 . The most commonly used forms of health care documentation 


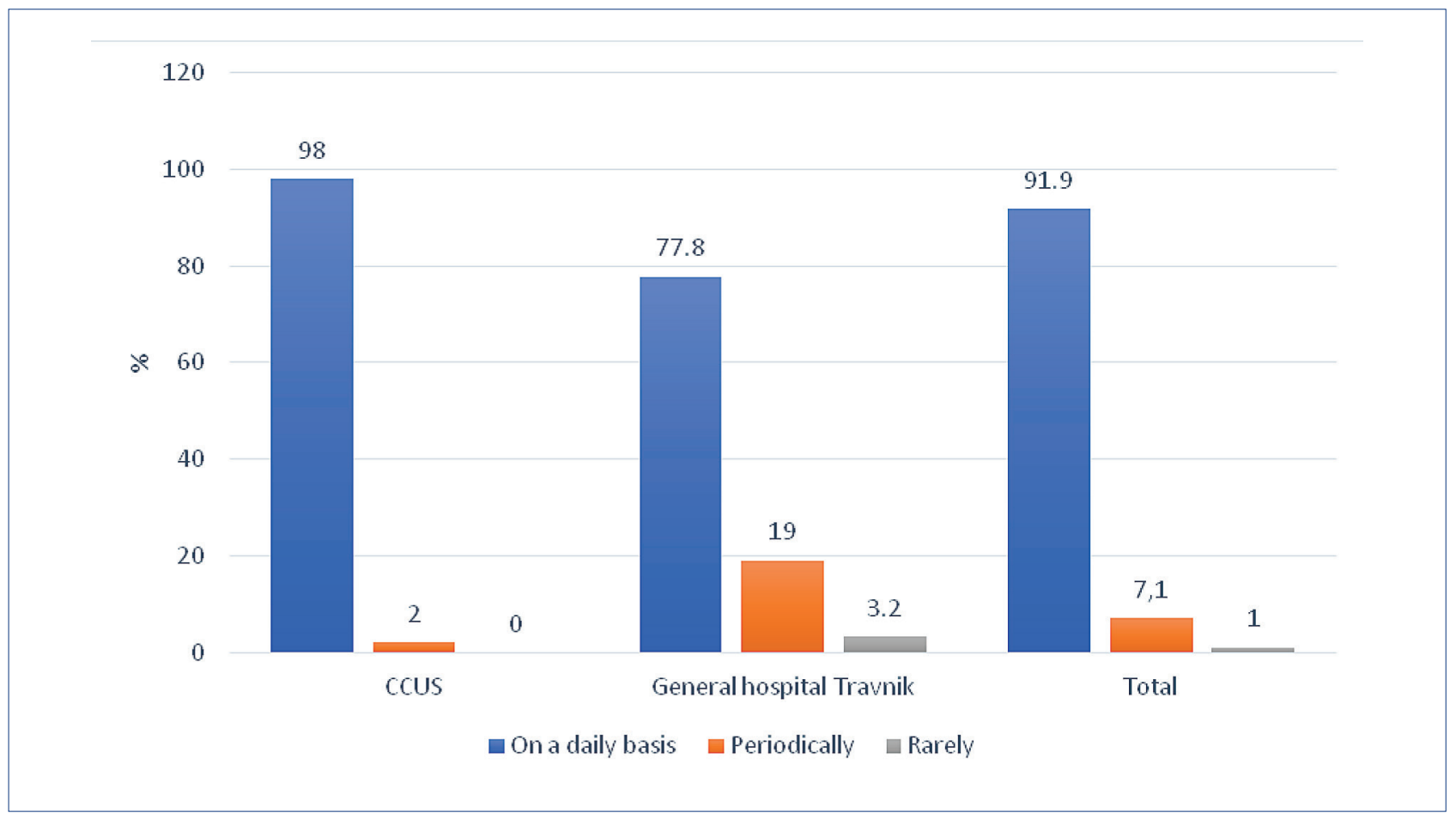

Figure 9. The practice of using health care documentation

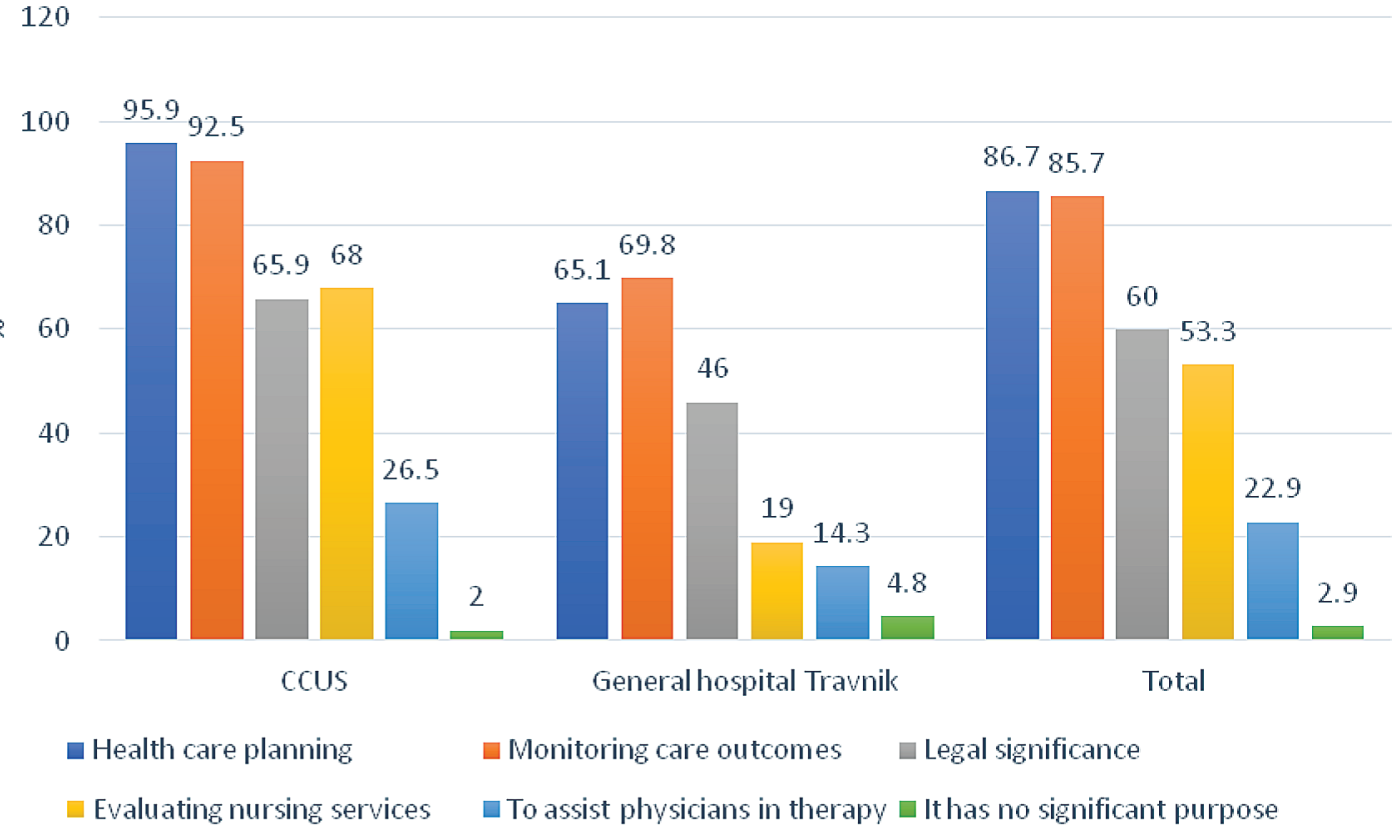




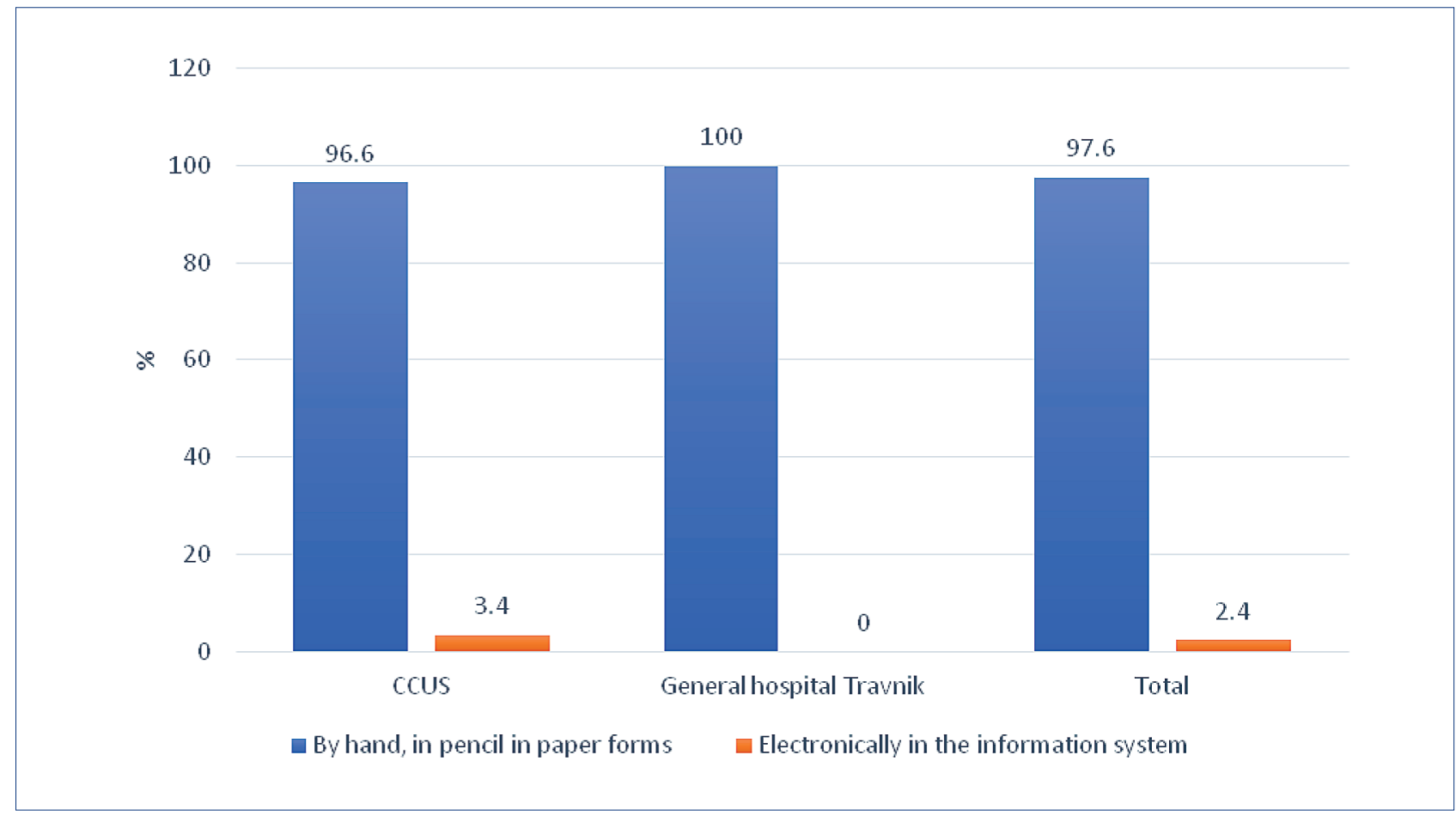

Figure 11. How the health care documenting is performed

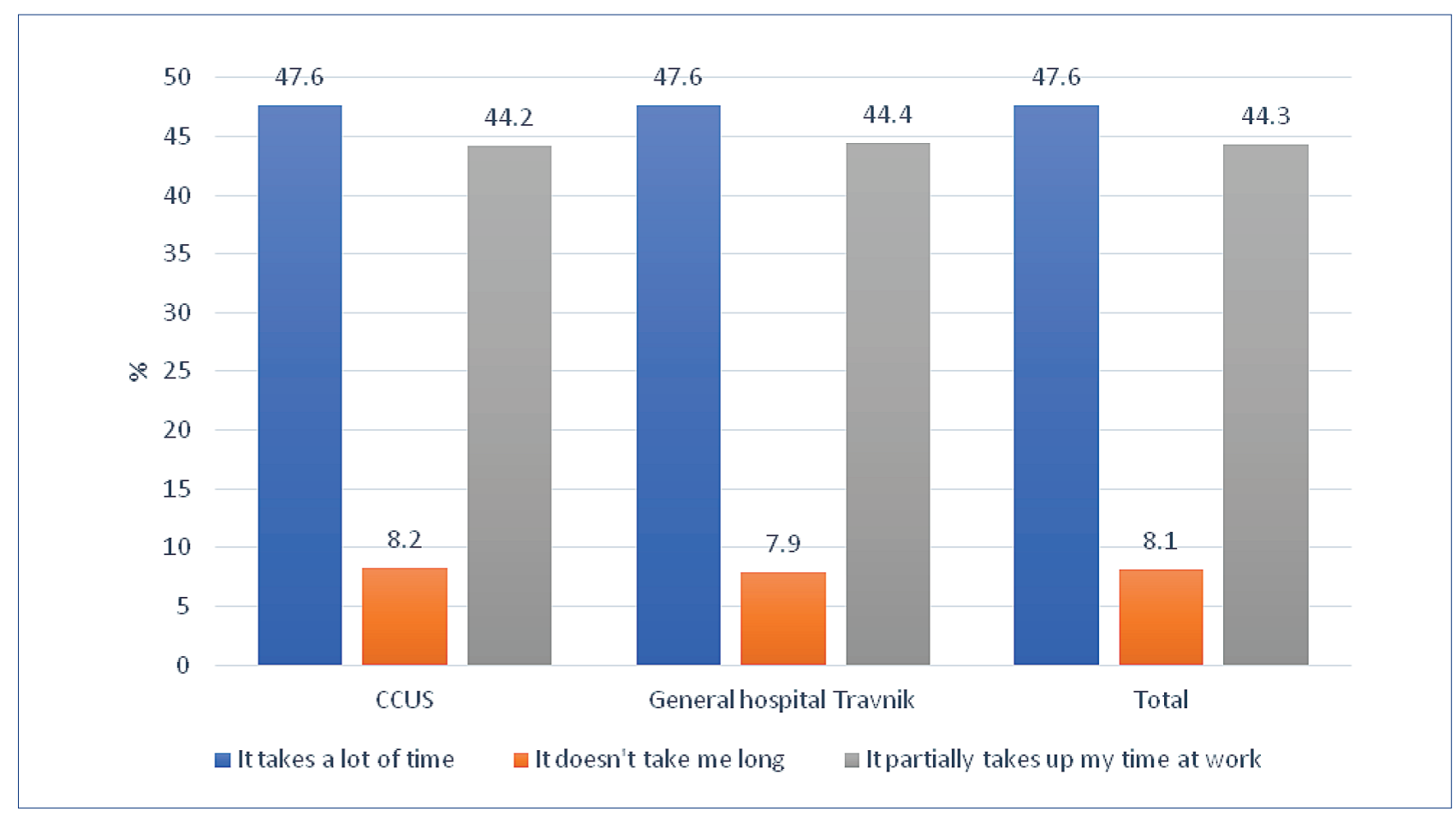




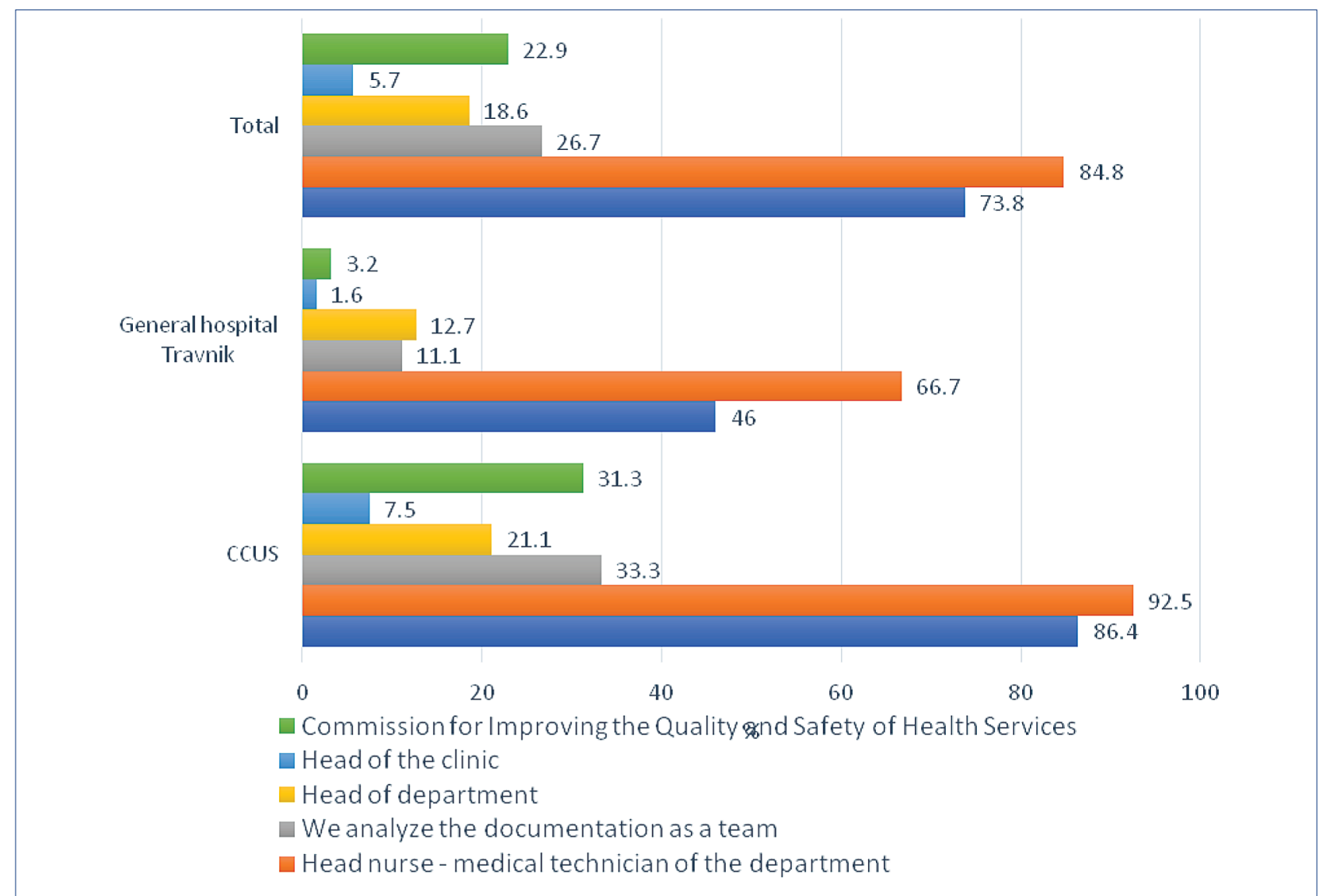

\section{Figure 13. Supervision of health care documentation}

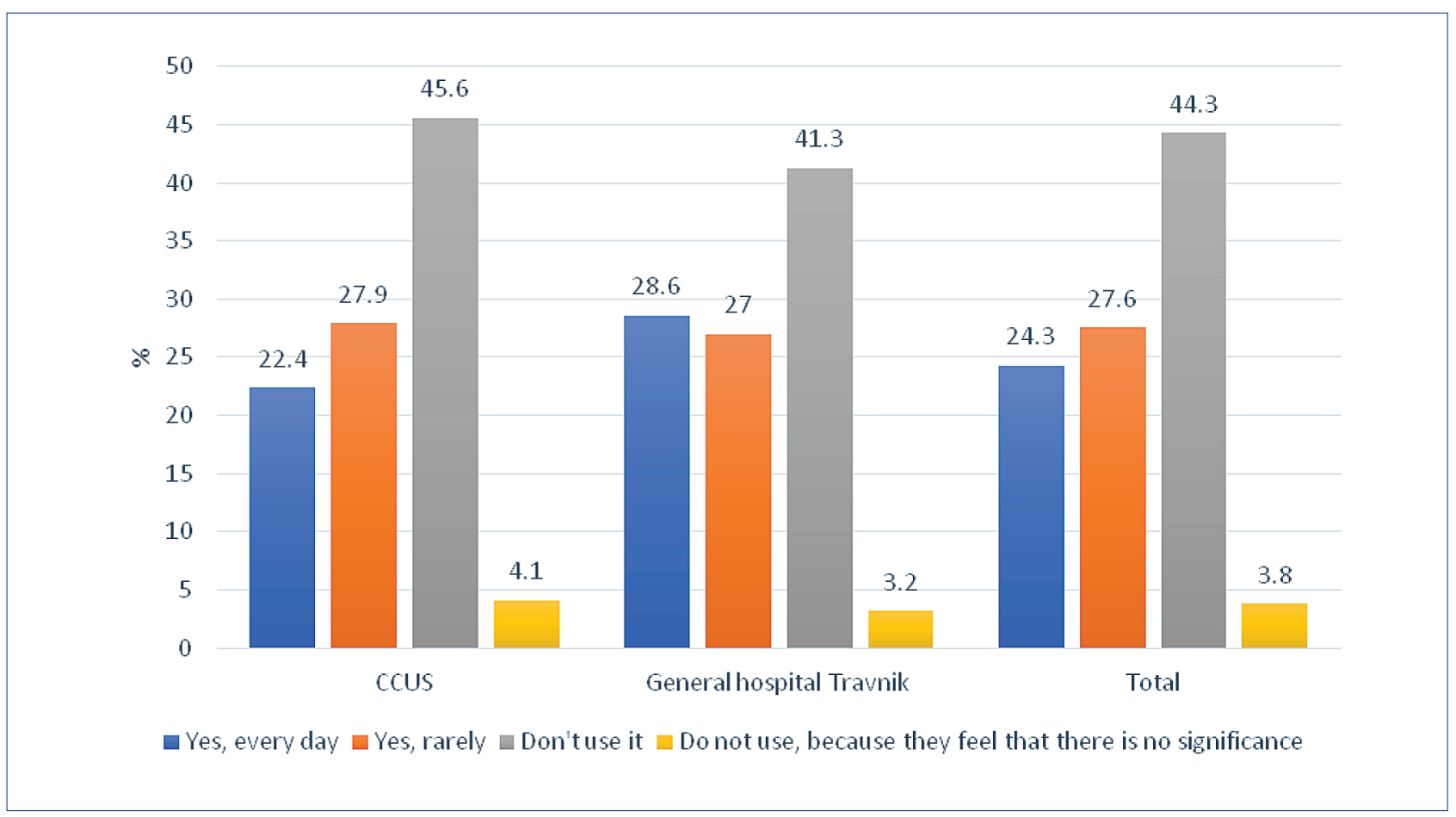




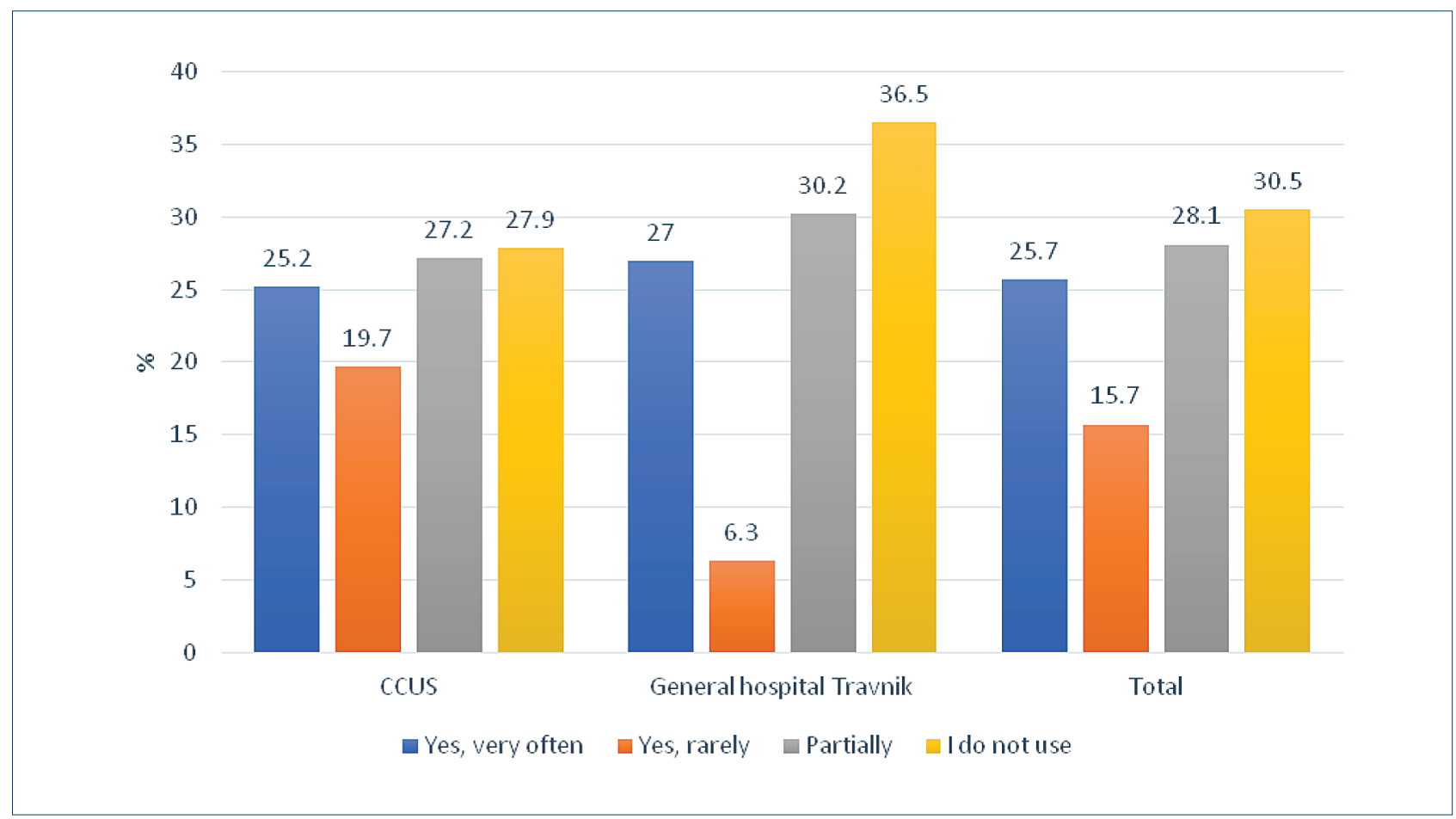

Figure 15. Using documentation to present a case

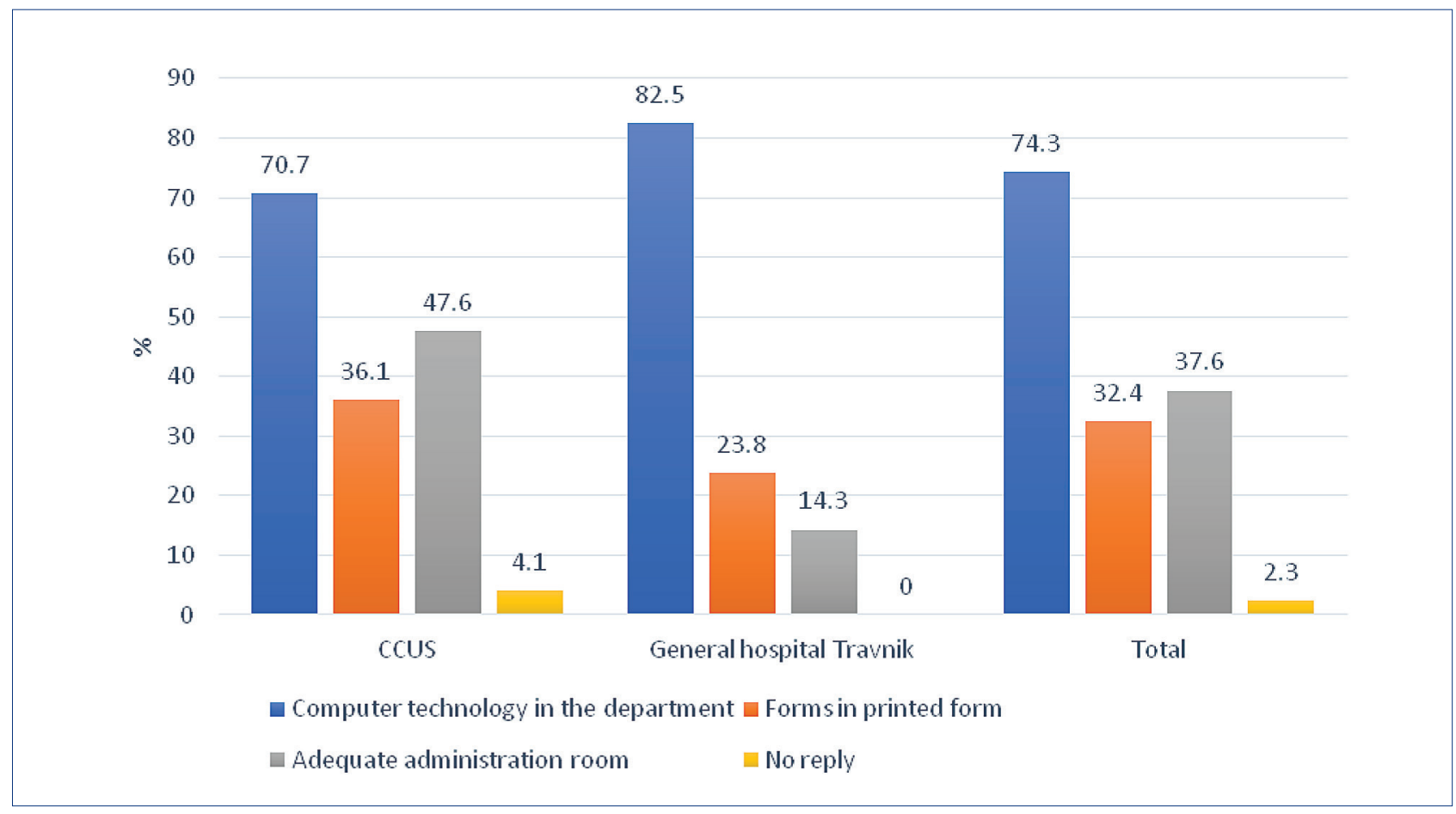




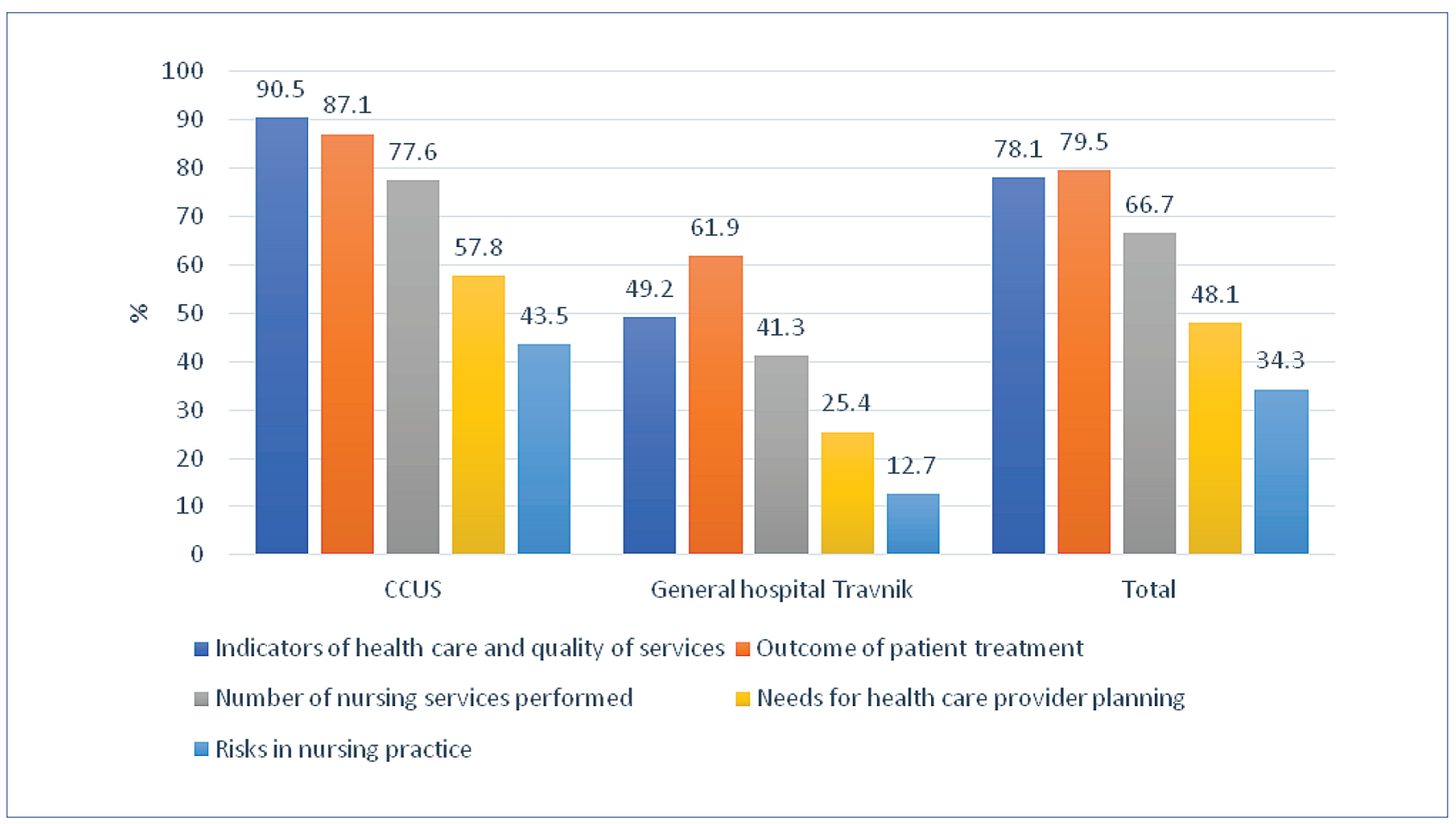

Figure 17. Parameters that can be monitored through health care documentation

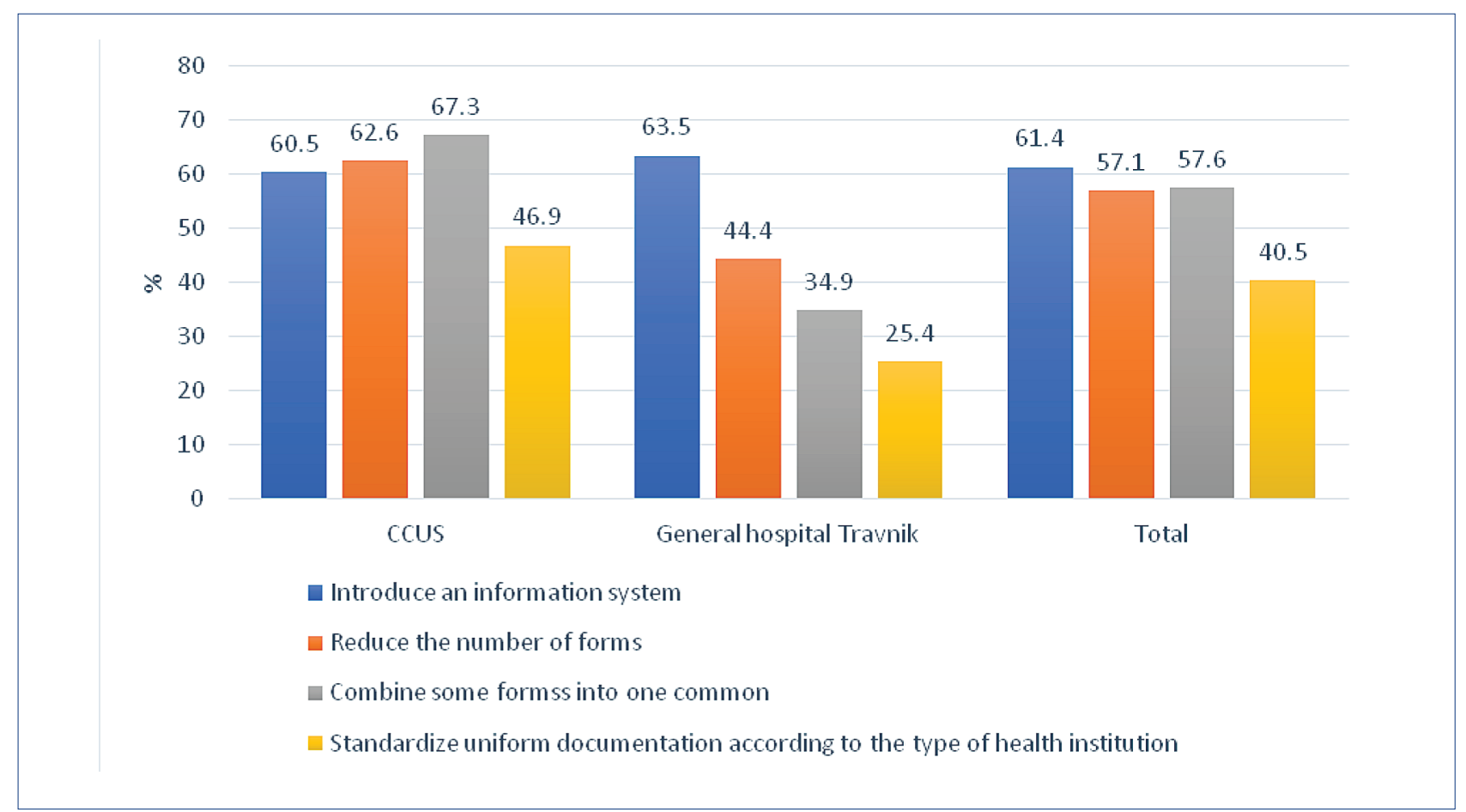




\section{Discussion}

The analysis of gender distribution shows that in the total sample $(n=210)$ nurses were more represented in 174 or $82.9 \%$ of cases compared to medical technicians who were represented with 36 or $17.1 \%$.

In both surveyed institutions, this ratio remained almost the same, and in CCUS ( $n=147)$ nurses were represented with 127 or $76.4 \%$ and medical technicians with 20 or $13.6 \%$ of cases.

In General hospital Travnik ( $\mathrm{n}=63$ ) nurses answered the questionnaire more often in 47 or $74.6 \%$ of cases compared to medical technicians who answered the questionnaire in 16 or $25.4 \%$ of cases.

The analysis of age in the total sample shows that the largest number of respondents was in the age group of $35-54$ years 143 or $68.1 \%$, then in the youngest age group of $18-34$ years 51 or $24.3 \%$, and the smallest in the oldest age group between 54 and 65 years -16 or $7.6 \%$.

In both centers, the respondents were most often between the ages of 54 and 65 years, 107 or $72.8 \%$ in CCUS and 36 or $57.1 \%$ in General hospital Travnik.

Statistical analysis by chi-square test shows that there is no significant difference in age between the observed hospitals $(p>0.05)$.

The analysis of years of service in the total sample shows that the largest number of respondents has 21 30 years of experience 77 or $36.7 \%$, followed by $11-20$ years of experience 62 or $29.5 \%$, less than 10 years 49 or $23.3 \%$ and at least over 30 years of service 22 or $10.5 \%$.

Statistical analysis by chi-square test shows that nurses-medical technicians of CCUS also statistically significantly have more years of work experience compared to nurses' technicians of General hospital Travnik $(p<0.05)$.

If we observe the total sample, the largest number of nurses-medical technicians who answered the questionnaire have secondary school in 121 or $57.6 \%$, then faculty education in 58 or $27.6 \%$, college in 20 or $9.5 \%$ while the least number are masters is 11 or $5.2 \%$.

The questionnaire was most often answered by nursesmedical technicians in 139 or $66.2 \%$, followed by head nurses-medical technician of the department in 49 or $23.3 \%$, and in the smallest number of head nurses-medical technicians of institutions in 22 or $10.5 \%$.
From CCUS, the largest number of respondents were nurses-medical technicians in 82 or $55.8 \%$, followed by head nurses-medical technicians of the department in 44 or $29.9 \%$ and the smallest number of head nursesmedical technicians of institutions in 21 or $14.3 \%$.

In the General hospital Travnik the respondents answered the questionnaire in a similar proportion, but more often nurses-medical technicians in 57 or $90.5 \%$, then head nurses-medical technicians of the department in 5 or $7.9 \%$ and one or $1.6 \%$ head medical nursemedical technician of the institution.

Statistical analysis indicates a significant difference between institutions $(p<0.05)$.

If we look at the total sample, the largest number of nurses-medical technicians believe that the institution where they work has adopted policies and procedures on how to manage nursing documentation in 163 or $77.6 \%$ of cases, partly in 41 or $19.5 \%$ and that they have not adopted procedures in 6 or $2.9 \%$.

The percentage of positive responses was higher in CCUS 141 or $95.9 \%, 6$ or $4.1 \%$ considered that the procedures were partially adopted while none of the nursesmedical technicians considered that they did not adopt the procedures.

Nurses-medical technicians of the Travnik Hospital mostly believe that the procedures were partially adopted in 35 or $55.6 \%$, that they were fully adopted in 22 or $34.9 \%$ and that they were not adopted in 6 or $9.5 \%$.

Statistical analysis indicates that a statistically significantly higher number of CCUS respondents considered that the procedures were adopted $(p<0.05)$.

The most commonly used forms of nursing care are the health care plan in $77.6 \%$, followed by the admission/ transfer list with a medical history in $75.2 \%$, the categorization of patients in $68.1 \%$ and the nursing list for monitoring pressure ulcers in $68.1 \%$. The least used was list for monitoring pain in $7.6 \%, 7.1 \%$ stated that they did not have standardized forms, and 39.5\% kept records.

In CCUS, the most frequently used documentation is the health care plan in $97.6 \%$ and the admission/transfer list with a nursing history in $97.6 \%$, and in third place in terms of the frequency of use is the patient categorizations in $93.9 \%$. From baseline $24.5 \%$ state that they use notebooks for records, and that they do not have standardized forms 3.4\%.

In General hospital Travnik, they most often use notebooks for records in $74.6 \%$, health care plan in $30.2 \%$, and 
in third place in terms of frequency, admission/transfer list with a nurse's anamnesis in $22.2 \%$. None of the respondents stated that they use a pain monitoring list, while $15.9 \%$ stated that they do not have standardized forms.

Statistical analysis indicates a significant difference according to the type of health care documentation used in these two health care institutions $(p<0.05)$.

If we analyze the average number of health care patterns used by nurses-medical technicians to document (answers are excluded from the sum does not have forms and we use notebooks) then we can see that in the total sample they use an average of 5.6 \pm 2.7 (from 1 to 10 ) forms.

Nurses-medical technicians of CCUS use significantly more forms, $7 \pm 1.6$ (from 1-10) compared to nursesmedical technicians of General hospital Travnik who use on average $2.2 \pm 1.5$ (from 1-6) forms.

Statistical analysis by Student's t test indicates a significant difference in the number of forms used by institutions $(p<0.05)$.

The largest number of nurses-medical technicians use medical records daily in 193 or $91.9 \%$, then occasionally 15 or $7.1 \%$ while only 2 nurses-medical technicians state that they rarely use health care records in their work.

A much larger number of CCUS nurses-medical technicians use this documentation on a daily basis 144 or $98.0 \%$, and 3 or $2.0 \%$ occasionally.

On the other hand, although the largest number of nurses-medical technicians at the Travnik Hospital use this documentation on a daily basis, 49 or $77.8 \%$, but in a smaller percentage compared to CCUS, 12 or $19 \%$ occasionally, while 2 or $3.2 \%$ do not use it at all.

Statistical analysis indicates a significant difference between the observed centers $(p<0.05)$.

In the overall sample, respondents most often believe that health care documentation has a purpose in health care planning in $86.7 \%$, followed by monitoring the outcome of care in $85.7 \%$ and legal significance in $60 \%$. Out of the total number, 6 or $2.9 \%$ of the respondents believe that the documentation has no significant purpose.

CCUS nurses-medical technicians most often believe that health care documentation has a purpose in health care planning in $95.9 \%$, then monitoring the outcome of care in $92.5 \%$ and evaluating nursing services in $68 \%$, while the smallest number believes that it has no significant purpose $2.0 \%$.
Nurses-medical technicians of General hospital Travnik most often believe that the documentation of health care has a purpose in monitoring the outcome of care in $69.8 \%$, planning health care in $65.1 \%$ and in legal significance in $46 \%$, while $4.8 \%$ believe that there is no significant purpose.

Statistical analysis indicates a significant difference between institutions $(p<0.05)$.

Respondents most often perform documentation of health care „by hand, in pencil in paper forms“ in 205 or $97.6 \%$, while only 5 or $2.4 \%$ do it electronically in information system.

Almost half of the respondents think that documenting the process of health care takes a lot of time 100 or $47.6 \%$, that it does not take a lot of time, 17 or $8.1 \%$, and that it partially takes their time at work, 93 or $44.3 \%$ respondents.

According to the centers, the distribution of responses is similar, so in CCUS 70 or $47.6 \%$ of nurses-medical technicians believe that documenting the health care process takes a lot of their time, that it does not take a lot of time, 12 or $8.2 \%$ and that it partially takes their time. in paper 65 or $44.2 \%$.

In the General hospital Travnik, 30 or $47.6 \%$ of nursesmedical technicians believe that documenting the health care process takes a lot of their time, that it does not take a lot of time, considers 5 or $7.9 \%$ and that it partially takes their time to work 28 or $44.4 \%$.

Statistical analysis indicates that there is no significant difference by centers in relation to this question ( $p>0.05$ ).

To make case presentation in practice, they use health care documentation very often in 54 or $25.7 \%$, rarely in 33 or $15.7 \%$, partially in 59 or $28.1 \%$ and do not use it at all in 64 or $30.5 \%$.

About half of the respondents from both institutions believe that doctors use health care documentation in their work, 51 or $24.3 \%$ every day, and rarely 58 or $27.6 \% .93$ or $44.3 \%$ of respondents think that they do not use it and that 8 or $3.8 \%$ of respondents think that they do not use it because it is irrelevant.

As the most common shortcomings, the respondents state the lack of information technology in the department in $74.3 \%$, then adequate premises for document administration in $37.6 \%$, the lack of forms in printed form in $32.1 \%$ and 6 or $2.3 \%$ of respondents did not answer these respondents.

In both institutions, the biggest shortcoming is the problem of computer equipment in the department, in 


\section{7\% in CCUS and $82.5 \%$ in General hospital Travnik.}

However, a significant $(p<0.05)$ difference occurs in the following answers because nurses-medical technicians as the second shortcoming in frequency identified the lack of adequate administration space in $47.6 \%$ and respondents from General hospital Travnik lack of forms in printed form in $28.8 \%$.

The most common recommendation in the total sample is the introduction of an information system in $61.4 \%$, then merging the forms into a common one in $57.6 \%$, reducing the number of forms in $57.1 \%$ and standardizing the documentation according to the type of health institution in $40.5 \%$.

Although there are certain deviations in the sense that the respondents of the Travnik Hospital put the information system in the first place, and CCUS combining several forms into one, these differences are not statistically significant $(p>0.05)$.

Previous research on documenting the health care process has mainly shown that keeping health care records helps nurses-technicians in their daily work, facilitates continuity in patient treatment, but also that there are certain difficulties since many nurses are not skilled in administration, especially electronic the manner of keeping medical records. ${ }^{12}$

Nowadays, when the scope of work has greatly increased in relation to service providers, i.e. health workers, it is of great importance to find a better, more reliable and faster way to enter and analyze data related to the patient and the health care he receives.

There are obstacles due to which the idea of informatization has not fully taken root, and these are: lack of computers, slow computer process and lack of knowledge and skills of medical staff in the field of technology. ${ }^{13}$

In a study conducted by the authors Kurtović B et al. an IT model for documenting health care was presented at the Clinic for Neurosurgery, Clinical Hospital Center "Sestre milosrdnice" in Zagreb.

In the practice of digitized form of nursing documentation, it is necessary to use all relevant components of nursing documentation. The content of the electronic form of the nursing list, as a relevant document, is the basis for the database of the development of the nursing part of monitoring the patient during his stay in the hospital. The paper points out that the electronic form of nursing documentation must be subject to change in order for the record to comply with applicable stand- ards. The combination and harmonization of all parameters enables better implementation in the information system, selection, classification and previously described storage and retrieval of data. ${ }^{14}$

In its paper, Čikeš M. emphasizes the importance of categorizing patients with the obligatory use of health care documentation, which can be used to calculate the time a nurse spends in the process of health care and its administration. ${ }^{15}$

\section{Conclusions}

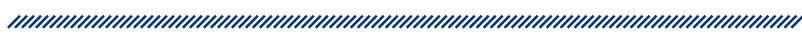

The study revealed that over $95 \%$ of respondents use standardized health care processes in their daily practice, document health care, know the basic purpose and monitor health care indicators. This was proven based on the answers of the respondents at the Clinical Center of the University of Sarajevo, where the program of establishing the quality and safety of health services has been implemented for more than 10 years. In relation to the respondents of the General Hospital Travnik, where a smaller number of respondents document health care, and most often use notebooks for health care records in $74.6 \%$.

More than $90 \%$ of respondents in both study groups use health care documentation to plan health care and monitor its outcomes.

More than half of the respondents in both study groups stated that documenting health care is a problem for them because it takes a lot of their time.

A larger number of respondents from both groups, as many as $30 \%$, state that they do not use the data from the health care documentation for any purpose.

In general, respondents from both institutions, in large number, stated that doctors very rarely use health care documentation in their work. However, indirectly there is a better system of monitoring nursing documentation in CCUS based on the observed parameters, and in CCUS nurses-medical technicians state that they are more valued, i.e. that doctors use their documentation more often and that there are fewer consequences for patients.

The lack of staff in the health care process, insufficient knowledge of information technologies, and the lack of an information system represent an aggravating circumstance in documenting the health care process. 


\section{References}

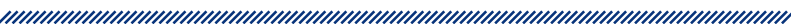

1. Proces sestrinske njege i dokumentacija. U: Lemon- priručnici za medicinske sestre. Sarajevo, 1999.g.

2. Čukljek, S. Teorija i organizacija u zdravstvenoj njezi nastavni tekstovi. Zagreb: Zdravstveno veleučilište u Zagrebu; 2008.

3. Fučkar, G. Proces zdravstvene njege. Zagreb: Medicinski fakultet Sveučilišta u Zagrebu; 1995.

4. Prlić N. Opća naĉela zdravlja i njege. Zagreb. Školska knjiga; 2014.

5. Zakon o sestrinstvu i primaljstvu FBiH ("Službene novine FBiH“, broj 43/13)

6. Ljubičić M. Implementacija sestrinske dokumentacija u informacijski zdravstveni sistem i utjecaj na kvalitetu zdravstvene njege. Diplomski rad. Zdravstveno veleučilište Zagreb, Specijalistički diplomski stručni studij Menadžment u sestrinstvu. Zagreb, 2010.

7. Henderson V. Osnovna načela zdravstvene njege. HUSE, HUMS. Zagreb, 1994.

8. Kalauz S. Upravljanje kvalitetom u zdravstvenoj njezi. Visoka zdravstvena škola Zagreb. Zagreb 2010.g.
9. Ovčina A. i aut. Menadžment standardizacije zdravstvene njege i značaj za reformske procese u zdravstvu. Dani Fakulteta zdravstvenih studija. Univerzitet u Sarajevu, Sarajevo, decembar 2018.g.

10. Križić J. Primjena sestrinske dokumentacije u bolničkom zdravstvenom sustavu. Završni rad. Visoka tehnička škola u Bjelovaru.Preddiplomski stručni studij sestrinstva. Bjelovar, svibanj 2018.g.

11. Fruk Marinković M. Kontinuirana odgovornost za profesionalnost i informacijsku pismenost u medicinskih sestara. Acta medica Croatica. 2014;68:1

12. Galić-Gavran M. Kradljivci vremena u sestrinskoj praksi. Diplomski rad. Sveučilište „Josipa Jurja Strossmayera“ Medicinski fakultet Osijek. Sveučilišni diplomski studij sestrinstva Osijek, 2016.

13. Häyrinen K, Lammintakanen J, Saranto K. Evaluation of electronic nursing documentation-Nursing process model and standardized terminologies as keys to visible and transparent nursing. Int J Med Inform 2010; 79: 554-64.

14. Kurtović, B. i aut. Informatizacija zdravstvene njege. Acta Medica Croatica. 2014. 68: 55-59.

15. Čikeš M. Utvrđivanje potreba za zdravstvenom njegom primjenom kategorizacije pacijenta. Graduation thesis. Dubrovnik: Sveučilište u Dubrovniku; Odjel za stručne studije, 2017. 


\section{UPRAVLJANJE DOKUMENTACIJOM ZDRAVSTVENE NJEGE U BOLNIČKIM UVJETIMA}

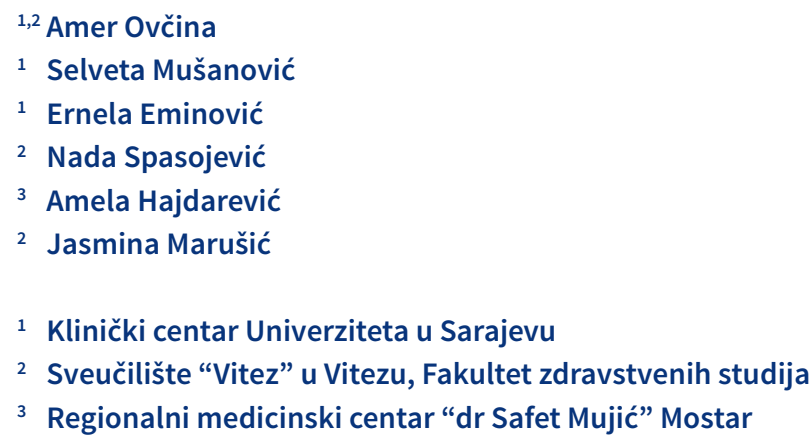

\section{Sažetak}

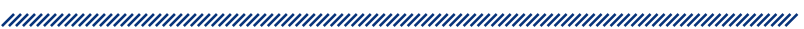

Dokumentacija zdravstvene njege ili sestrinska dokumentacija, kako se često naziva u praksi, neizostavan je dio medicinske dokumentacije pacijenta, a dokumentiranje je sastavni dio svakodnevnoga sestrinskog posla. Dokumentiranje zdravstvene njege u bolnici podrazumijeva zapisivanje podataka o svim provedenim postupcima tijekom cjelokupnog procesa zdravstvene njege za pojedinca, a sve u svrhu sustavnog praćenja stanja te planiranja i vrednovanja kvaliteta zdravstvene njege. Sestrinska dokumentacija služi kao sredstvo komunikacije između tima i od velike je važnosti za kvalitetu i kontinuitet zdravstvene njege.

CILJEVI RADA: 1. Utvrditi postojanje dokumentacije zdravstvene njege u bolničkim zdravstvenim ustanovama. 2. Ispitati praksu medicinskih sestara/tehničara u procesu administriranja zdravstvene njege. 3. Prikazati indikatore kvalitete koji se prate i analiziraju putem do- kumentacije zdravstvene njege. 4. Komparirati dobivene rezultate u dva ispitivana područja.

METODE RADA: Ovo istraživanje provedeno je na dva geografski odvojena područja, u Sarajevu i Travniku. $\mathrm{U}$ istraživanju je sudjelovalo 210 ispitanika, i to 147 medicinskih sestara/tehničara zaposlenih u Kliničkom centru Univerziteta u Sarajevu i 63 medicinske sestre / medicinska tehničara zaposlena u Općoj bolnici u Travniku. Prikupljanje podataka za istraživanje provedeno je deskriptivnom metodom. Za deskriptivno istraživanje primijenjen je originalni autorski upitnik. Upitnik je ispitanicima bio dostupan u elektroničkom obliku u internetskoj aplikaciji Google Forms. Anonimnost ispitanika bila je u potpunosti zajamčena. Istraživanje je provedeno u periodu od 15. srpnja do 15. kolovoza 2019.

REZULTATI ISTRAŽIVANJA: U Kliničkom centru Univerziteta u Sarajevu 98 \% ispitanika svakodnevno upotrebljava obrasce dokumentacije zdravstvene njege, a u Općoj bolnici Travnik 77,8 \% ispitanika. U KCU-u Sarajevo ispitanici više upotrebljavaju standardizirane obrasce dokumentacije zdravstvene njege, i to 97,6\%, u odnosu na ispitanike u Općoj bolnici u Travniku, gdje se dokumentiranje vrši u sestrinske evidencijske bilježnice, i to 74,6 \%. $68 \%$ ispitanika u KCU-u Sarajevo smatra da dokumentiranje pridonosi vrednovanju sestrinskih usluga, dok to smatra samo $19 \%$ ispitanika iz Opće bolnice Travnik. Kao najčešće nedostatke ispitanici navode nedostatak računalne tehnike na odjelu $(74,3 \%)$, zatim neadekvatne prostorije za administriranje dokumentacije $(37,6 \%)$ te nedostatak obrazaca u tiskanom obliku (32,1\%), a na ovo pitanje nije odgovorilo šest ili $2,3 \%$ ispitanika.

$\mathrm{U}$ obje ustanove kao najveći nedostatak navode problem računalne opreme na odjelu, i to $70,7 \%$ u KCU-u Sarajevo i 82,5\% u OB-u Travnik. 
ZAKLJUČCl: Istraživanjem je utvrđeno da više od $95 \%$ ispitanika u svakodnevnoj praksi primjenjuje standardizirane procese zdravstvene njege, dokumentira zdravstvenu njegu, poznaje osnovnu svrhu i prati indikatore zdravstvene njege. Više od $90 \%$ ispitanika u obje ispitivane skupine dokumentacijom zdravstvene njege koristi se za planiranje zdravstvene njege i praćenje njezinih ishoda.Više od polovine ispitanika u obje ispitivane skupine navelo je da im dokumentiranje zdravstvene njege predstavlja problem jer im oduzima mnogo vremena u radu. Veći broj ispitanika obje ispitivane skupine, čak $30 \%$, navodi da se podacima iz dokumentacije zdravstvene njege ne koriste ni u kakve svrhe. Nedostatak izvršitelja procesa zdravstvene njege, nedovoljno znanje o informacijskim tehnologijama te nepostojanje informacijskog sustava predstavlja otežavajuću okolnost u dokumentiranju procesa zdravstvene njege. 